\title{
PENGEMBANGAN KETERAMPILAN BERPIKIR KREATIF SISWA PADA PRAKTIKUM JENIS-JENIS KOLOID: PENDEKATAN SAINSTIFIK
}

\author{
Sari $^{1}$, Resti Yulianti Hidayat ${ }^{2}$ \\ 1 Pendidikan Kimia Fakultas Tarbiyah dan Keguruan UIN Sunan Gunung Djati \\ Bandung Jl. A.H Nasution No.105 Cibiru-Bandung 46014 Indonesia \\ 1 Lab Mikrobiologi. Jl. Cidahu Parungkuda, Kab. Sukabumi \\ Email:riechemistry@gmail.com
}

\begin{abstract}
ABSTRAK
Karakteristik ilmu kimia yang sulit dipahami menuntut adanya keterampilan berpikir yang mendalam dan kreatif. Oleh karena itu diperlukan adanya bimbingan untuk siswa dalam meningkatkan keterampilan berpikir kreatif melalui penerapan pendekatan saintifik pada praktikum jenis-jenis koloid dengan mengembangkan beberapa indikator dari keterampilan berpikir kreatif tersebut. Tujuan penelitian ini diarahkan untuk menganalisis keterampilan berpikir kreatif setelah mengikuti pembelajaran dengan pendekatan saintifik pada subkonsep jenis-jenis koloid. Metode yang digunakan dalam penelitian ini adalah penelitian kelas. Instrumen yang digunakan adalah LKS dan lembar soal tes keterampilan berpikir kreatif. Teknik pengumpulan data penelitian ini melalui pengisian LKS, pengisian soal tes KBKf dan observasi. Hasil penelitian menunjukan 79,5\% aktivitas siswa terlaksana dengan baik. Berdasarkan hasil tes KBKf, siswa pada kelompok atas dan kelompok rendah termasuk ke dalam kategori baik sekali dengan nilai masing-masing 81,4 dan 85,2 dan untuk kelompok sedang mendapat nilai 79,5 dengan kategori baik. Sedangkan kemampuan siswa berdasarkan LKS dari ketujuh subindikator keterampilan berpikir kreatif yang dapat dikembangkan memperoleh nilai rata-rata 79,6 dengan kategori baik.
\end{abstract}

Kata Kunci : Jenis-jenis Koloid, Keterampilan Berpikir Kreatif, Pendekatan Saintifik, Praktikum.

\begin{abstract}
The characteristics of elusive chemistry needs deep and creative thinking skills. Therefore, it is necessary to improve students in increasing their creative thinking skills through the application of scientific approach in practical work of the types of colloids by developing some indicators of the creative thinking skills. The purpose of this research are to analyzes creative thinking skills after participating in the scientific approach to learn other types of colloidal subconcepts. The methode used in this research is class. The instrument used in this research are worksheets, creative thinking skills tests sheets. The techniques of collecting data in this research are answering the $L K S$, answering $K B K f$ tests, and observing. The results shows that $79.5 \%$ of students activities are running well. Based on the KBKf test result, the students in the upper and lower groups belong to excellent category get score 81,4 and 85,2. In addition, intermediate group gets score 79.5 with good category. Then, the students ability based on LKS from seven sub-indicators of creative thinking skills which can be developed get average score 79.6 with good category.
\end{abstract}

Keywords: the types of colloids, creative thinking skills, scientific approach, practical work 


\section{PENDAHULUAN}

Ilmu kimia berkaitan dengan cara mencari tahu tentang alam secara sistematis, sehingga sains bukan hanya penguasaan kumpulan pengetahuan yang berupa fakta-fakta, konsep-konsep, atau prinsip-prinsip saja tetapi juga merupakan suatu proses penemuan (Depdiknas, 2003: 6). Berdasarkan definisi di atas dapat dilihat bahwa konsep kimia begitu luas, mulai dari konsep yang sederhana sampai konsep yang sangat kompleks.

Kehidupan manusia tidak dapat terlepas dari kimia, seluruh fenomena yang terjadi di bumi ini sangat berkaitan erat dengan kimia seperti, proses perkaratan besi, proses pencernaan dan proses kimia lainnya. Sehingga ilmu kimia memberikan banyak manfaat bagi manusia. Namun, berdasarkan fakta penelitian yang dilakukan sebelumnya oleh Phitaloka (2011: 82), menunjukkan bahwa 73\% siswa menyatakan kimia merupakan pelajaran yang sulit, bahkan ada 3\% siswa yang menyatakan mata pelajaran kimia paling sulit dibandingkan dengan mata pelajaran lain. Dari hasil studi pendahuluan dengan guru mata pelajaran kimia di SMAN 26 Bandung ini menyebutkan bahwa 70\% siswa masih mempelajari kimia dengan teknik menghapal saja, sehingga dibutuhkan keterampilan berfikir kreatif (KBKf) untuk menunjang itu semua agar ilmu kimia itu tampak lebih menarik dan menyenangkan.

Usaha untuk memenuhi harapan tersebut guru perlu memperhatikan proses berpikir siswa dan pembelajaran di kelas yang dilakukan seharusnya sudah sesuai dengan karakteristik kimia yang menuntut siswa untuk berpikir mendalam dan kreatif agar siswa memiliki kemampuan berpikir dan bertindak berdasarkan pengetahuan kimia yang dimilikinya (Liliasari, 2008: 2). Salah satu konsep kimia adalah koloid. Berdasarkan hasil studi pendahuluan yang dilakukan di SMAN 26 Bandung, salah satu guru kimia menuturkan belum pernah melaksanakan pembelajaran yang berorientasikan pada pengembangan keterampilan berpikir kreatif. Selain itu, dalam mempelajari koloid terutama pada subkonsep jenis-jenis koloid siswa masih tertukar dalam membedakan beberapa jenis koloid.

Oleh karena itu, untuk lebih memahami beberapa jenis koloid diperlukan pendekatan pembelajaran yang dapat menjelaskan konsep tersebut. Salah satu pendekatan yang dapat mengatasi permasalahan kesulitan tersebut serta mengembangkan keterampilan berpikir kreatif (KBKf) siswa yaitu dengan menerapkan pendekatan saintifik, sehingga diharapkan dapat melahirkan peserta didik yang produktif, kreatif, inovatif, dan afektif melalui penguatan sikap, keterampilan, dan pengetahuan yang terintegrasi (Daryanto, 2014: 59). Langkahlangkah pada pendekatan saintifik merupakan bentuk adaptasi dari langkah-langkah ilmiah pada sains yang meliputi tahapan mengamati, menanya, mengumpulkan data, mengasosiasi dan mengkomunikasikan (Daryanto, 2014:59).

Berdasarkan permasalahan yang telah diuraikan, perlu adanya metode pembelajaran pendukung yang efektif dan sesuai agar masalah tersebut dapat teratasi. Metode yang dapat mengatasi permasalahan ini adalah dengan metode praktikum. Sebagaimana Rustaman (2006: 2) mengemukakan bahwa praktikum dapat meningkatkan motivasi untuk mempelajari sains dan dapat meningkatkan keterampilan-keterampilan dasar bereksperimen. Tujuan penelitian ini untuk menganalisis keterampilan berpikir kreatif siswa setelah pembelajaran dengan menggunakan pendekatan saintifik.

Pembelajaran saintifik sering juga disebut dengan pendekatan ilmiah atau inquiry method yaitu pembelajaran yang seluruh aktivitas dilakukan oleh siswa untuk mencari dan menemukan jawaban sendiri dari sesuatu yang dipertanyakan (Sanjaya, 2010: 197). Menurut Daryanto (2014: 59) terdapat 5 tahapan dalam pembelajaran saintifik yaitu tahapan mengamati, menanya, mengumpulkan data, mengasosiasi, dan mengomunikasikan.

Keterampilan berpikir kreatif merupakan kemampuan menemukan banyak kemungkinan jawaban terhadap suatu masalah berdasarkan data atau informasi yang ada, dimana penekanannya adalah pada kuantitas, ketepatgunaan dan keragaman jawaban (Munandar, 1999: 48). Adapun Indikator atau ciri-ciri keterampilan berpikir kreatif (Aptitude) menurut Munandar (2009:80) adalah sebagai berikut:

a. Keterampilan berpikir lancar

b. Subindikator yang digunakan: mengajukan banyak pertanyaan, mempunyai banyak gagasan mengenai suatu hal, dan menjawab dengan sejumlah jawaban jika ada pertanyaan.

c. Keterampilan berpikir luwes

d. Keterampilan berpikir orisinal

e. Subindikator yang digunakan: mempertanyakan cara-cara yang lama dan berusaha memikirkan cara-cara yang baru dan setelah membaca atau mendengar gagasangagasan, bekerja untuk menemukan penyelesaian yang baru.

f. Keterampilan memperinci

g. Keterampilan menilai 
h. Subindikator yang digunakan: menentukan pendapat sendiri mengenai suatu hal dan mempunyai alasan yang dapat dipertanggungjawabkan untuk mencapai suatu keputusan.

Emulsi adalah suatu campuran koloid hasil dispersi dua cairan yang tidak dapat bercampur. Dalam hal ini, digunakan suatu zat pengemulsi atau emulgator, seperti sabun atau gelatin. Ada dua macam emulsi yaitu minyak terdispersi dalam air dan air terdispersi dalam minyak. Contoh sistem (air dalam minyak): susu, minyak ikan. Contoh sistem (minyak dalam air): pelumas

Gel adalah semacam koloid dengan partikel padat yang biasanya merupakan molekul besar, bergabung secara tak teratur dan membentuk struktur yang salin terjalin menghasilkan campuran yang kaku. Misalnya pektin dari buah-buahan menghasilkan "jelly" buah-buahan (Achmad, 2001: 212).

\section{METODE PENELITIAN}

Metode yang digunakan dalam penelitian ini adalah metode penelitian kelas. Metode ini bertujuan untuk menganalisis KBKf siswa pada pembelajaran jenis-jenis koloid. Cara untuk menganalisis hal tersebut digunakan beberapa instrumen yaitu deskripsi pembelajaran, LKS, tes KBKf, serta rubrik penilaian LKS dan tes KBKf.

Data yang diperoleh dianalisis dengan cara mengatur urutan data, mengelompokan data dan mengorganisasikan data ke dalam kategori yang akan diteliti, selanjutnya data diolah secara statistik.

Subyek dalam penelitian ini adalah siswa kelas XI IPA 5 di SMAN 26 Bandung, yang berjumlah 35 orang terdiri dari 15 orang siswa laki-laki dan 20 orang siswa perempuan.

\section{HASIL DAN PEMBAHASAN}

Nilai rata-rata tiap tahap pembelajaran pendekatan saintifik pada Subkonsep jenis-jenis koloid untuk setiap kelompok belajar siswa disajikan pada tabel 1.

Tabel 1. Nilai Rata-rata Setiap Tahap Pendekatan Saintifik pada Subkonsep Jenis-jenis Koloid Berdasarkan Kelompok Belajar

\begin{tabular}{|c|c|c|c|c|c|c|c|}
\hline \multirow{2}{*}{ No } & \multirow{2}{*}{ Kel } & \multicolumn{5}{|c|}{ Tahapan Saintifik } & Rata- \\
\cline { 3 - 7 } & & I & II & III & IV & V \\
\hline
\end{tabular}

\begin{tabular}{|l|c|c|c|c|c|c|c|}
\hline 1 & 1 & 100 & 100 & 77 & 83 & 83 & 88,6 \\
\hline 2 & 2 & 66 & 66 & 55 & 100 & 73 & 72,0 \\
\hline 3 & 3 & 100 & 100 & 66 & 66 & 73 & 81,0 \\
\hline 4 & 4 & 100 & 100 & 88 & 100 & 83 & 94,2 \\
\hline 5 & 5 & 66 & 66 & 88 & 83 & 90 & 78,6 \\
\hline 6 & 6 & 33 & 33 & 88 & 83 & 83 & 64,0 \\
\hline $\begin{array}{l}\text { Rata- } \\
\text { Rata }\end{array}$ & $\mathbf{7 7 , 5}$ & $\mathbf{7 7 , 5}$ & $\mathbf{7 7 , 0}$ & $\mathbf{8 5 , 8}$ & $\mathbf{8 1 , 0}$ & $\mathbf{7 9 , 7}$ \\
\hline
\end{tabular}

Keterangan :

Tahap I : Mengamati

Tahap II : : Menanya

Tahap III : : Mengumpulkan Data

Tahap IV : : Mengasosiasi

Tahap V : Mengkomunikasikan

Nilai tertinggi pada setiap tahap pembelajaran pendekatan saintifik yaitu pada tahap mengasosiasi. Nilai terendah dari semua tahap pembelajaran pendekatan saintifik adalah pada tahap mengumpulkan data dengan nilai 77. Hal ini menunjukkan bahwa siswa dalam melakukan praktikum pada tahap mengasosiasi mengalami kemajuan, dan secara tidak langsung siswa telah mengembangkan keterampilan berpikir kreatifnya pada indikator setelah membaca atau mendengar gagasan-gagasan, bekerja untuk menemukan penyelesaian yang baru dan menjawab dengan sejumlah jawaban jika ada pertanyaan. Selain pada tahap mengasosiasi tahap mengomunikasikan juga mengalami kemajuan yang sangat baik dengan rata-rata nilai 81,0 yang secara tidak langsung siswa telah mengembangkan keterampilan berpikir kreatifnya pada indikator menentukan pendapat sendiri mengenai suatu hal dan mempunyai alasan yang dapat dipertanggungjawabkan untuk mencapai suatu keputusan.

Keterampilan berpikir kreatif siswa didapat dari tes tertulis yang diberikan kepada siswa setelah pembelajaran selesai. Siswa mengerjakan soal ini secara individu. Adapun hasil analisisnya dapat dilihat pada tabel 2 .

Berdasarkan Tabel 2. di atas, nilai rata-rata untuk setiap kelompok prestasi adalah kelompok rendah dengan rata-rata nilai 85,2 , kelompok tinggi dengan rata-rata nilai 81,4 , dan kelompok sedang dengan rata-rata nilai 79,5 .

Tabel 2. Hasil Tes Keterampilan Berpikir Kreatif Siswa untuk Setiap Indikator Berdasarkan Kelompok Prestasi

\begin{tabular}{|c|c|c|c|c|c|c|c|}
\hline Kel. & \multicolumn{5}{|c|}{ Indikator } & Rata- & Inter- \\
rata & prestasi \\
\cline { 2 - 7 }
\end{tabular}




\begin{tabular}{|c|c|c|c|c|c|c|c|}
\hline Tinggi & 71,4 & 92,8 & 76,1 & 76,1 & 90,4 & 81,4 & $\begin{array}{c}\text { Baik } \\
\text { sekali }\end{array}$ \\
\hline Sedang & 66,6 & 88,0 & 76,1 & 79,3 & 87,3 & 79,5 & Baik \\
\hline $\begin{array}{c}\text { Rendah } \\
\text { Rata- }\end{array}$ & 64,2 & 85,7 & 95,2 & 85,7 & 95,2 & 85,2 & $\begin{array}{c}\text { Baik } \\
\text { sekali }\end{array}$ \\
\hline $\begin{array}{c}\text { Rata } \\
\text { rata }\end{array}$ & $\mathbf{8 8 , 8}$ & $\mathbf{8 2 , 5}$ & $\mathbf{8 0 , 4}$ & $\mathbf{9 1 , 0}$ & $\mathbf{8 2 , 0}$ & $\begin{array}{c}\text { Baik } \\
\text { sekali }\end{array}$ \\
\hline
\end{tabular}

Keterangan :

Indikator 1: Mempunyai banyak gagasan mengenai suatu masalah

Indikator 2: Menjawab dengan sejumlah jawaban jika ada pertanyaan

Indikator 3: Mempertanyakan cara-cara yang lama dan berusaha memikirkan cara- cara yang baru

Indikator 4: Mengajukan banyak pertanyaan

Indikator 5: Menentukan pendapat sendiri mengenai suatu hal

Secara keseluruhan keterampilan berpikir kreatif siswa setiap tahapan pembelajaran saintifik adalah sebagai berikut:

\section{a. Tahap mengamati}

Perolehan nilai rata-rata tertinggi pada tahap ini diperoleh oleh kelompok 1, 3, dan 4 yaitu dengan nilai 100 . Nilai tersebut didapatkan karena dapat dilihat dari cara menuangkan dalam bentuk penyajian pertanyaan yang mereka ajukan secara relevan sesuai dari apa yang telah mereka baca dan amati dari wacana. Perolehan nilai rata-rata LKS terendah pada tahap ini diperoleh oleh kelompok 6 dengan nilai 33. Kelompok tersebut mendapatkan nilai terendah karena dilihat dari cara mengamati dan menyimak wacana yang kurang antusias dan dipengaruhi oleh minat baca anggota kelompoknya sehingga hasil yang didapatkan tidak sesuai. Sedangkan nilai rata-rata LKS kelompok siswa pada tahapan ini yaitu sebesar 77,5 dengan interpretasi baik, dengan demikian pencapaian indikator keterampilan berpikir kreatif pada tahap ini juga bisa dikatakan baik.

Tinggi atau rendahnya nilai siswa disebabkan karena faktor pengetahuan yang berbeda-beda atau karena cara belajar dan berpikir siswa yang berbeda-beda. Sebagaimana menurut Costa (dalam Samosir, 2010: 11) bahwa proses berpikir yang dilakukan siswa dapat berupa berpikir dasar (berpikir rasional) dan berpikir kompleks (tingkat tinggi).

\section{b. Tahap menanya}

Nilai rata-rata LKS pada tahap menanya untuk semua kelompok yaitu 77,5 dengan interpretasi baik. Keterampilan berpikir kreatif pada tahap ini juga terlaksana dengan baik. sebagaimana menurut
Machin (2014: 31) Karakter yang muncul dalam kegiatan menanya adalah mengembangkan kreativitas, rasa ingin tahu, kemampuan merumuskan pertanyaan untuk membentuk pikiran kritis dan belajar sepanjang hayat. Hal ini membuktikan kemampuan siswa dalam mengajukan banyak pertanyaan terlaksana dengan baik.

c. Tahap mengumpulkan data

Nilai rata-rata LKS pada tahap mengumpulkan data untuk semua kelompok yaitu 77 dengan interpretasi baik. Keterampilan berpikir kreatif pada tahap ini juga terlaksana dengan baik. Kelompok yang paling menonjol pada tahap ini yaitu kelompok 4, 5 dan 6 dengan nilai 88. Meskipun memiliki interpretasi baik tapi tahap ini merupakan tahap yang memiliki nilai rata-rata LKS terendah yang didapatkan oleh semua kelompok. Hal ini mungkin terjadi karena kebebasan yang guru berikan dalam menentukan sumber yang mereka baca, kebanyakan kelompok menggunakan hanya satu sumber saja yaitu internet. Begitupun dengan indikator berpikir kreatif pada tahap ini meskipun terlaksana dengan baik akan tetapi kurang bisa dikembangkan pada tahap ini, yang seharusnya keterampilan berpikir kreatif bisa mengembangkan beberapa kemampuan seperti kemampuan pemecahan masalah, kemampuan menulis dan membaca berbagai macam sumber pada tahap ini (Wang, 2011: 1).

\section{d. Tahap mengasosiasi}

Salah satu bahan yang mereka bawa untuk praktikum emulsi yaitu telur, kelompok 5 menggunakan kuning telur saja untuk dijadikan emulgator, kelompok 3 menggunakan putih telurnya dan kelompok yang lain menggunakan semua bagian dari telur tersebut. Hasil yang diperoleh siswa tentu saja berbeda setiap kelompoknya dan ini akan menjadi pembahasan menarik bagi siswa dan mengasah keterampilan berpikir mereka untuk memecahkan masalah yang dialami, sebagaimana menurut Wena (2011: 138) bahwa salah satu usaha mendorong agar siswa menjadi kreatif dapat dilakukan dengan beberapa cara, diantaranya dengan mengembangkan beberapa pemecahan masalah yang kreatif untuk suatu masalah yang siswa tersebut alami yang berkaitan dengan konsep yang dipelajari.

Tahap mengasosiasi memperoleh nilai rata-rata 85 dengan interpretasi sangat baik. Hasil tersebut juga dapat menjelaskan bahwa keterampilan berpikir kreatif pada tahap ini dapat berkembang dengan sangat baik, seperti yang diungkapkan oleh Putra (2013: 134) bahwa salah satu tujuan dari metode 
praktikum ialah agar siswa mampu mengumpulkan fakta-fakta, informasi, atau data-data yang diperoleh, melatih siswa dalam merancang, mempersiapkan, melaksanakan, dan melatih siswa dalam menggunakan logika berpikir guna menarik kesimpulan dari fakta, informasi, atau data yang terkumpul melalui percobaan. Dalam tahap ini membuktikan kemampuan siswa dalam bekerja untuk menemukan penyelesaian yang baru dapat dikembangkan dengan sangat baik.

\section{e. Tahap mengomunikasikan}

Berdasarkan hasil analisis rata-rata nilai LKS pada setiap tahapan, nilai rata-rata LKS pada tahap mengkomunikasikan yaitu sebesar 81 dengan interpretasi baik sekali. Kelompok 5 mendapatkan nilai tertinggi 90, dengan kualitas baik dalam menyimpulkan dan mempresentasikan pada tahap ini seperti disaat mempresentasikan kelompok ini mampu mengaitkan hasil percobaannya dengan beberapa teori. Identifikasi siswa yang menunjukkan hasil yang jauh lebih baik ini menjadi indikasi bahwa siswa mampu mengembangkan keterampilan berpikir kreatifnya dalam hal menentukan pendapat sendiri dan mempertanggungjawabkannya (Munandar, 1999: 90). Secara keseluruhan kinerja siswa atau kemampuan siswa dalam menyelesaikan LKS untuk setiap tahapan pendekatan saintifik pada konsep jenis-jenis koloid menunjukan nilai rata-rata 79,7 dengan interpretasi baik.

Nilai rata-rata dari setiap indikator KBKf setelah pembelajaran secara keseluruhan adalah 82,06 berada di atas KKM sudah mencapai ketuntasan. untuk indikator mempunyai banyak gagasan mengenai suatu masalah, kelompok prestasi tinggi, sedang, dan rendah mendapat nilai berturut-turut 71,$42 ; 66,66$ dan 64,28 . Nilai rata-rata tertinggi diperoleh kelompok prestasi tinggi dan nilai terendah diperoleh kelompok prestasi rendah. Hasil ini sesuai dengan pendapat Rebber (1988 dalam Syah, 2009:123) kelompok prestasi tinggi memiliki strategi kognitif yang lebih baik untuk menguji keandalan gagasan pemecahan masalah dan mengatasi kesalahan atau kekurangan .

Indikator menjawab dengan sejumlah jawaban jika ada pertanyaan kelompok prestasi tinggi, sedang dan rendah mendapat nilai secara berturut-turut yaitu 92,$85 ; 88,09$ dan 85,71 . Nilai rata-rata tertinggi diperoleh kelompok prestasi tinggi.

Nilai tertinggi pada Indikator mempertanyakan cara-cara yang lama dan berusaha memikirkan caracara yang baru diperoleh oleh kelompok prestasi rendah. Hasil tersebut dikarenakan kepintaran seseorang tidak menjamin mereka berhasil dalam kehidupan sehari-hari bila tidak diasah dan dilatih (Yamin, 2012: 159).

Indikator mengajukan banyak pertanyaan, kelompok prestasi tinggi mendapatkan nilai 76,18, kelompok prestasi sedang mendapatkan nilai 79,64, dan untuk kelompok prestasi rendah mendapatkan nilai 85,71 . Nilai rata-rata tertinggi diperoleh oleh kelompok prestasi rendah dan nilai terendah diperoleh oleh kelompok prestasi tinggi. Hal tersebut dikarenakan seseorang yang kreatif adalah yang memiliki kemampuan pemahaman, sensitivitas, dan apresiasi, dapat dikatakan melebihi dari seseorang yang tergolong intelegen (Ausubel, 1986 dalam Hamalik, 2008: 12). Dari pernyataan tersebut dapat diartikan bahwa seseorang yang memiliki kecerdasan tinggi belum tentu memiliki kreativitas yang tinggi.

Nilai tertinngi untuk indikator menentukan pendapat sendiri mengenai suatu hal diperoleh kelompok prestasi rendah dengan nilai 95,24 dan nilai terendah diperoleh oleh kelompok prestasi sedang.

Perbedaan hasil tes keterampilan berpikir kreatif antara kelompok prestasi tinggi, sedang dan rendah menjadi ukuran bahwa keterampilan berpikir kreatif siswa berbeda-beda. Nilai rata-rata tes keterampilan berpikir kreatif kelompok prestasi rendah ternyata lebih tinggi dari kelompok prestasi sedang dan tinggi, hal tersebut dapat terjadi karena berbagai macam faktor yang melatarbelakanginya. Menurut Santrock (2004: 155) menyatakan bahwa hasil tersebut dapat terjadi bukan karena faktor kecerdasan akan tetapi karena faktor gaya belajar dan berpikir. Ada pula pendapat lain yang menyebutkan penyebab terjadinya hasil tes tersebut dikarenakan pengaruh yang muncul dari faktor intern siswa yang meliputi gangguan atau kekurangmampuan psikofisik siswa baik yang bersifat kognitif, afektif, maupun psikomotor, serta faktor ekstern siswa yang meliputi semua situasi dan kondisi lingkungan sekitar yang tidak mendukung aktivitas belajar siswa seperti lingkungan keluarga, lingkungan masyarakat dan lingkungan sekolah (Syah, 2009: 184).

\section{KESIMPULAN}

Keterampilan berpikir kreatif siswa sesuai tahapan pendekatan saintifik melalui praktikum jenis-jenis koloid berdasarkan lembar kerja siswa (LKS) secara keseluruhan dikategorikan baik dengan rata-rata nilai 79,6 dan Keterampilan berpikir kreatif siswa 
secara keseluruhan setelah proses pembelajaran memperoleh nilai rata-rata 82,0 dengan kategori baik sekali sehingga dapat dilihat dari nilai tersebut bahwa terjadi pengembangan Keterampilan berpikir kreatif siswa pada saat proses pembelajaran dan setelah proses pembelajaran menggunakan tahapan pendekatan saintifik.

\section{DAFTAR PUSTAKA}

Achmad, Hiskia. (2001). Penuntun Belajar Kimia Dasar: Kimia Larutan. Bandung: PT. Citra Aditya Bakti.

Arikunto, Suharsimi. (2010). Prosedur Penelitian Suatu Pendekatan Praktik. Jakarta: PT. Rineka Cipta.

Daryanto. (2014). Pendekatan Pembelajaran Saintifik Kurikulum 2013. Yogyakarta: Gava Media.

Depdiknas. (2003). Sains. Jakarta: Depdiknas.

Liliasari. (2008). Peningkatan Kualitas Pendidikan Kimia dari Pemahaman Konsep Kimia Menjadi Berpikir Kimia. [Online]. Tersedia: http://file.upi.edu. [diakses 1 Juni 2015].

Machin, A. (2014). Implementasi Pendekatan Saintifik, Penanaman Karakter dan Konservasi Pada Pembelajaran Materi Pertumbuhan. Jurnal Pendidikan IPA Indonesia, 1, 28-35.

Munandar, Utami. (2009). Pengembangan Kreativitas Anak Berbakat. Jakarta: Rineka Cipta.

Anonim. (1999). Mengembangkan Bakat dan Kreativitas Anak Sekolah. Jakarta: Gramedia Widiasarana Indonesia.
Phitaloka, Yunita. (2011). Analisis Hasil Belajar Level Makroskopik, Mikroskopik, dan Simbolik Siswa SMA pada Materi Pokok Kelarutan dan Hasil Kali Kelarutan. Skripsi Sarjana pada FPMIPA UPI Bandung: Tidak Diterbitkan.

Putra, Sitiatava Rizema. (2013). Desain Belajar Mengajar Kreatif Berbasis Sains. Jogjakarta: DIVA Press.

Rustaman. (2006). Strategi Belajar Mengajar Biologi. Malang: UM Pres.

Samosir, H. (2010). Model Pembelajaran POEW (Predict Observe Explain Write) untuk meningkatkan penguasaan konsep kalor dan Keterampilan Berpikir Kritis SMA. Tesis. UPI. Bandung: tidak diterbitkan.

Sanjaya, Wina. (2009). Kurikulum dan Pembelajaran: Teori dan Praktik Pengembangan Kurikulum Tingkat Satuan Pendidikan (KTSP). Jakarta: Kencana Prenada Media Group.

Santrock, Jhon W. (2004). Psikologi Pendidikan. Jakarta: Kencana.

Syah, Muhibbin. (2009). Psikologi Belajar. Jakarta: Rajawali Pers.

Wang, Amber. (2011). Context of Creative Thinking: A Comparison on Creative Performance of Student Teachers in Taiwan and the United States. Journal of International and CrossCurtural Studies. 2, (1), 1-14.

Wena, Made. (2011). Strategi Pembelajaran Inovatif Kontemporer: sutatu tinjauan konseptual operasional. Jakarta : Bumi Aksara. 